\title{
Terrorism, Fulani herdsmen and the forced migration of Christians and Igbo Indigines from Northern Nigeria: The revalidation of Biafra?
}

\section{Christian Chima Chukwu ${ }^{1}$, Anyaoha Okechukwu ${ }^{2}$}

\author{
${ }^{1}$ Department of Sociology/Intelligence and Security Studies. Novena University. \\ Ogume. Delta State. Nigeria. Email:chukwuchidr@gmail.com. \\ ${ }^{2}$ Department of Sociology. Imo State University. Owerri. Nigeria.
}

\begin{abstract}
This paper highlights terrorism, Fulani herdsmen and the forced migration of Christians and Igbo indigenes from Northern Nigeria, and the revalidation of Biafra following the killings of hundreds of Christians, and Igbo indigenes, and destruction of their properties running into billions of Naira in Borno, Yobe, Gombe, Bauchi, Adamawa, Taraba, Kaduna, Plateau, Benue, Nassarawa and Kogi States. However, the recent slaughter of innocent Nigerians in Benue State including the senseless slaughter of two Catholic priests and their parishioners by marauding Fulani herdsmen heightened the insecurity in Nigeria. Data depended on both primary and secondary sources and literatures related to the variables were reviewed. Aggression and Frustration theory was employed to provide a foundation for the study. Among the findings, the study revealed that the terrorism has become a national menace affecting socio-economic and political development of the country. The study showed that the Boko Haram deadly attacks have not only destroyed hundreds of lives and properties worth billions of naira, but also culminated in the forced migration of both Christians and Igbo Indigenes seeking greener pastures from Northern Nigeria. The study, furthermore, revealed that the current wave of uncertainties in Nigeria is a bye product of an accumulated deprivation, destruction, marginalization, anger and frustration of Christians of the north central geographical zone who would prefer to join their Igbo counterparts to be self ruled in their proposed creation: Biafra. Based on this, the study therefore recommends that the government should protect and safeguard Christians of the north central geographical zone and Igbo Indigenes from being massacred and their properties running into billions of naira destroyed so as to save Nigeria from splitting into 'Banana Republics'. Secondly, the government should address the symptoms of terrorism and the deadly and continued invasion of Fulani herdsmen rather than the root cause in order to resolve the crisis and halt the dismemberment of the Nigeria nation. Furthermore, the Muslim leaders should inculcate in their members high ethical standards, respect for human life, dignity and also ensure that their adherents are more loving and tolerant of other people and other religions. Finally, the study concludes
\end{abstract}

Received: Jun. 23, 2018

Accepted: Aug. 10, 2018

Released: Aug. 31, 2018

Open access

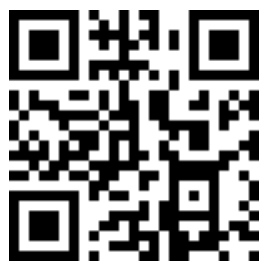

ORCID

구 0000-0002-4290-243X Christian Chima Chukwu

D 0000-0001-7170-6690 Anyaoha Okechukwu 
that since Nigeria is a pluralist society, the government should through the mass media emphasize the essence of peaceful coexistence so as to engender national integration.

Keywords: Terrorism; Fulani herdsmen; Forced migration; Christians; Igbo Indigenes.

Resumo. Terrorismo, pastores Fulani e a migração forçada de cristãos e índios Igbo do norte da Nigéria: a revalidação do Biafra? Este artigo destaca o terrorismo, os pastores Fulani e a migração forçada de cristãos e Igbinos do Norte da Nigéria, e a revalidação de Biafra após os assassinatos de centenas de cristãos e índios Igbo e a destruição de suas propriedades em bilhões de Naira, nos Estado de Borno, Yobe, Gombe, Bauchi, Adamawa, Taraba, Kaduna, Plateau, Benue, Nassarawa e Kogi. No entanto, o recente massacre de nigerianos inocentes no Estado de Benue, incluindo a matança sem sentido de dois padres católicos e seus paroquianos por vilões saqueadores de Fulani, aumentaram a insegurança na Nigéria. Os dados aqui apresentados derivaram de fontes primárias e secundárias e literatura relacionadas ao tema foram revisadas. A teoria de agressão e frustração foi empregada para fornecer uma base para o estudo. Entre os resultados, o estudo revelou que o terrorismo tornou-se uma ameaça nacional que afeta o desenvolvimento socioeconômico e político do país. 0 estudo mostrou que os ataques mortais do Boko Haram não só destruíram centenas de vidas e propriedades no valor de bilhões de nairas, mas também culminaram com a migração forçada de cristãos e indígenas Igbo em busca de pastos mais verdes do norte da Nigéria. 0 estudo, além disso, revelou que a atual onda de incertezas na Nigéria é um produto derivado de uma privação acumulada, destruição, marginalização, raiva e frustração dos cristãos da zona geográfica central do norte que preferem unir-se a seus homólogos Igbo para serem auto-governados., em sua proposta de criação: Biafra. Com base nisto, o estudo recomenda, portanto, que o governo proteja e resguarde os cristãos da zona geográfica norte-central e indígenas Igbo de serem massacrados e que suas propriedades sejam destruídas em bilhões de nairas, a fim de evitar que a Nigéria divida-se em "Republicas de Bananas". Em segundo lugar, o governo deveria abordar os sintomas do terrorismo e a invasão mortal e continuada dos Pastores Fulani, em vez da causa principal, a fim de resolver a crise e suspender o desmembramento da nação nigeriana. Além disso, os líderes muçulmanos devem inculcar em seus membros elevados padrões éticos, respeito pela vida humana, dignidade e também assegurar que seus adeptos sejam mais amorosos e tolerantes com outras pessoas e outras religiões. Finalmente, o estudo conclui que, como a Nigéria é uma sociedade pluralista, o governo deveria, através dos meios de comunicação de massa, enfatizar a essência da coexistência pacífica, de modo a engendrar a integração nacional.

Palavras-chave: Terrorismo; Pastores Fulani; Migração forçada; Cristãos; Indígenas Igbo. 


\section{Introduction}

In the aftermath of the heartbreaking events of September 11, 2001, several prominent arm-chair critics, spectators, as well as academics have called for increased support and educational cum learning assistance to end terrorism. This thesis tends to consent to the fact that there is surprisingly new evidence that provides optimism that a reduction in poverty or an increase in educational attainment would meaningfully reduce terrorism (Mehmood, 2014) and by extension, the Fulani herdsmen deadly attacks. In disagreement with this misleading notion, Krueger and Malečková (2003) aver that any connection between poverty, education and terrorism has the capacity of duplicity, complication and probably ambiguous. Therefore, instead of viewing terrorism and the Fulani herdsmen deadly attacks as direct responses to low market opportunities or ignorance, it is more accurately to be viewed as a response to political conditions and long-standing feelings of indignity, accumulated deprivation, subjugation, anger, frustration, and marginalization that have little to do with economics. Based on this, terrorism is difficult to define; in fact, studies have found more than 200 definitions of terrorism. In fact, Simon (1994) argues that at least 212 different definitions of terrorism exist across the world; 90 of them are recurrently used by governments and other institutions. Succinctly put, there is no universally agreed-on definition of terrorism despite the avalanche of famous scholars.

Nevertheless, it seems apt to define the term terrorism in this study so as to elucidate the perception the authors of this paper hold to halt being taken out of context. Be it as it may, within terrorism lies the word terror (Burgess, 2003). According to Burgess (2003), terror comes from the Latin terrere, which means "frighten" or "tremble". When coupled with the French suffix isme (referencing "to practice"), it becomes akin to "practicing the trembling" or "causing the frightening." Trembling and frightening here are synonyms for fear, panic, and anxiety what we would naturally call terror. The word terror is over 2,100 years old. In ancient Rome, the terror cimbricus was a state of panic and emergency in response to the coming of the Cimbri tribe killers in 105 BCE.

Basically, the word terrorism, in and of itself, was coined during the French Revolution's Reign of Terror (1793-1794). According to Burke (1790), in the Reign of Terror (Le Gouvernement de la Terreur), a group of rebels, the Jacobins, used the term when selfreflexively portraying their own actions in-and explanations of-the French Revolution. Substantiating, Burke asserted that the Reign of Terror was a campaign of large-scale violence by the French state; between 16,000 and 40,000 people were murdered in a little over a year. It is not astonishing, subsequently, that the French National Convention stated publicly in September 1793 that "terror is the order of the day". Similarly, Maximilien Robespierre, a frontrunner in the French Revolution, affirmed in 1794 that "terror is nothing other than justice, prompt, severe, inflexible". The very first certified definition of terrorism in French was provided several years later. In 1798, the French released the supplement for the dictionary of the Académie Française, an elite French learned body on matters dealing with the French language. In this supplement, the term was explained as the "système, régime de la terreur" (i.e., "government of terror"). The English version of the word terrorism is attributed to a British man's depiction of the bloodshed he had witnessed from afar in France, where the revolution was happening. Sir Edmund Burke commented on the French Revolution and warned about 
"thousands of those hell hounds called terrorists" (Burke, 1790).

From this perspective, the U.S. Department of Defense (1983) views, in spite of this clarification, that the term "terrorism", means "premeditated, politically motivated violence perpetrated against noncombatant targets by sub-national groups or clandestine agents, usually intended to influence an audience" (Krueger and Malečková, 2003). Eight years after, the U.S. Department of Defense in one of its releases reviewed terrorism as:

The calculated of unlawful violence or threat of unlawful violence to inculcate fear; intended to coerce or to intimidate governments or societies in the pursuit of goals that are generally political, religious or ideological.

Similarly, the American Federal Bureau of investigation (FBI), on its part, defines terrorism as:

The unlawful use of force and violence and violence against persons or property to intimidate or coerce a government, the civilian population, or any segment thereof, in furtherance of political or social objectives.

In the face of this array of definitions, the Longman Dictionary of Contemporary English has joined in the fray to put forward a definition of terrorism as "the use of violence such as bombing, shooting or kidnapping to obtain political demands...". For Sederberg (2003), terrorism is the employment of "a technique of political influence that has not been limited to specific weapons... a tactic that all political contenders may be tempted to use if it seems likely to be effective". The African Union (AU) Convention on Prevention and Combating Terrorism (1994) has presented a more concise definition as " any act which is a violation on the criminal... which may endanger the life, physical integrity or freedom of, or cause serious injury or death to any person, any number or group of persons or causes or may cause damage to public or private property, natural resources, environmental or cultural heritage and is calculated or intended to (a) intimidate, put fear, coerce or induce any government, body, institution, the general public or any segment thereof, to do or abstain from doing any act, or to adopt or abandon a particular standpoint or to act according to certain principles; or (b) disrupt any public service, the delivery of any essential service to the public or to create a public emergence; or create general insurrection in a state. In a nutshell, the impact of terrorist violence and damage reaches more than the immediate target victims (e.g., government or military). It is also directed at targets consisting of a larger spectrum of society (e.g., civilians or even society as a whole). As observed, terrorism is distinct from regular crime because of its powerful objectives. The change is desired so desperately that the inability to achieve change is perceived as a worse consequence than the deaths of civilians. Terrorist acts are both mala prohibita acts and mala in se acts. Mala prohibita acts are "crimes that are made illegal by legislation"; mala in se acts are crimes "that are immoral or wrong in themselves". Terrorism is, first and foremost, a method, and it is used in times of peace and conflict.

Boko Haram is an indigenous salafist group which turned itself into a salafist Jihadist in 2009 (Eme and Ibietan, 2012). Since the outburst of the Boko Haram, Nigeria's cohesion has been weakened more than ever before. This thesis arguably rests on the fact that Nigerian elites have sacrificed opportunities for initiating national integration on the altar of Short-term interest, thus compounding the problem of unity and the continued corporate existence of the country. Sequel to this anomaly, the country has remained plagued with conflicting interests that 
have given birth to terrorism via the nefarious activities of Boko Haram. The creation of Boko Haram was not accidental as many are made to acknowledge. It was systematically created. The group was founded by Mohammed Yusuf in 2002 in the city of Maiduguri with the aim of establishing a Sharia government in Borno State under the support and guidance of former Governor of the state. Furthermore, Mohammed Yusuf established a religious complex that included a Mosque and a school where many Muslim young children who could easily be radicalized and indoctrinated into the aforesaid thought across Nigeria and from neighbouring countries were enrolled at no cost. From the beginning, the manifest of the sect was known: Rejection of Western education, institutions, and agencies that go with it, including government institutions. It preferred to have a sharia law applied all over the country, but if that was difficult to grant, they would rather have a separate Islamic state carved out of Nigeria, where they could practice their religion unhindered. If this were not granted, Nigeria would be made ungovernable if and only when their demands were not granted. However, with the rejection of the demands which government classed as treasonable, unreasonable and unacceptable, minor skirmishes which later snow-balled arose between security agencies and the dissident sect. Nevertheless, the emergence of Abubakar Shekau, after the death of Mohammed Yusuf, their foremost leader in 2009, reinvented violence and began what could best be described as the bombardment of Northern Nigeria with such frequency and intensity that were quite unprecedented in history of violence in Nigeria. Ever then, Igbo Indigenes have been killed and, the surviving having very horrible tales to tell (Chukwu, 2013)

While scholars were rationalizing the outburst of Boko Haram and its terrorist activities, there emerged the
Fulani herdsmen whose uninterrupted attacks occur at the least provocation leading to a series of senseless killings which has continued to breed inexplicable fear into the psyche of Nigerian Christians. Basically, numerous scholars have argued that the national intelligence which is a critical tool of statecraft, and which also provides the necessary warning about imminent threats are now entirety in the hands of a section of the country and as such nothing could be done to curtail the threats which comes from within the same section that controls national intelligence and security architecture in the country. The costs in lives, aside from being devastating have left many Nigerian Christians and Igbo Indigenes wounded and others rendered homeless. Despite all efforts made to curtail the bloody and infamous activities, these sects have not been defeated by the Nigerian armed forces even up till date. They are still ravaging everywhere

From all available literatures, it is most disheartening to observe that the Fulani herdsmen and Boko Haram blood spilling activities find rationalization in the Quran:

Fight in the cause of God those who fight you, but do not transgress limits; for God loveth not transgressors. And slay them wherever ye catch them, and turn them out from where they have turned you out; for tumult and oppression are worse than slaughter; but fight them not at the sacred mosque, unless they(fight) you there; but if they fight you, slay them. Such is the reward of those who suppress faith. But if they cease, God is Oft-forgiving, most Merciful. And fight them on until there is no more tumult or oppression, and there prevail justice and faith in God; but if they cease, let there be no hostility except to those who practice oppression (S. 2:190-193).

One vexing issue that seems to emerge from the quoted verse is the 
continued onslaught against Igbos and Christians who seem not fighting them for any reason and are living their lives peaceably. In dodging the issue, some Muslim scholars have explained the Fulani herdsmen and Boko Haram infamous activities as emanating from some perceived acts of injustice. This lame duck explanation elicits a number of questions: (i) Acts of injustice by whom? (ii) How are Igbo Indigenes and Christians generally connected to the "acts of injustice" experienced by Muslim youths who are principally the bulk of Fulani herdsmen and Boko Haram? (iii) Why do Fulani herdsmen deadly attacks and Boko Haram terrorists target Igbos in their business premises and Christians in their churches?

While one ponders over these, it is central to understand that what is happening in Nigeria today has its origin in 1942; a concrete resolution of the emirs which was never challenged by the British. The West African Students' Union in London had in 1942, written to the Northern Emirs for co-operation with the South in order to reconstruct and fashion out a new Nigeria, but the Northern Emirs' response to that letter of appeal for co-operation with the South was acidic:

Holding this country together is not possible except by means of the religion of the Prophet... if they want political unity let them follow or religion (in Awolowo 1947:51)

The British government did not discourage this strong attitude of the Emirs. Instead they did everything, though very subtly, to aggravate it, or at least to keep it up. This anomaly by the British finds rationalization in the fact that the authoritarian regime of the Hausa/Fulani suited the monarchical rule of the British which eventually paved way for the success of indirect rule in Northern Nigeria, unlike those of the Igbo and Yoruba that were acephalous (headless) and democratic respectively that crumbled the indirect rule to the chagrin of the colonial master. However, consequent upon the intercourse between the British and the Hausa/Fulani, an education policy was designed for them to despise the South; the average educated Hausa/Fulani looks upon the educated southerner as an ungrateful rebel against his white benefactor (Awolowo, 1947). As ungrateful rebels, Igbos Indigenes have become the receptacles of anger, hatred, envy and frustration oozing out of their neighbours. Commenting on the fate of Igbos in Nigeria, the veteran American diplomat, Henry Kissinger, aptly observed that the Ibos are the wandering Jews of West Africa - gifted, aggressive, Westernized; at best envied and resented, but mostly despised by the mass of their neighbors in the Federation (1969). Corroborating the position of Kissinger, Kalu (2013) queried the continued Igbo massacred by northern Nigerian Muslims who have been provoked not by any direct misconduct by any Igbo but perhaps by the fact the Prophet Mohammed was insulted in Denmark by some European artists or that Allah's name was mentioned vaingloriously in Los Angeles by an American satirist. In spite of this resentment, Igbos are still compulsively seeking the positive and even trusting their abilities to survive the hatred, envy and frustration.

Without mincing words, the political implication of terrorism has been lethal to the extent that terrorism and insecurity have not only become the order of the day, but traumatizing to the democratic governance in Nigeria. It is in this light that Chukwurah et al. (2015) argue that terrorism has become a deliberate and systematic use of violence to destroy, kill, maim and intimidate the innocent in order to draw national/international attention or demands which ordinarily may be impossible or difficult to grant under normal political negotiation or on the battle field against a government army. 
With the recent attacks of Fulani herdsmen, particularly on churches and killing men of God, agitations for splitting Nigeria has increased. For both Boko Haram and Fulani herdsmen deadly attacks, there have been resultant increases in population displacement especially in the Benue plateau axis where their adherents are more active. This population displacement has worsened the social and economic situation in that region. Sequel to this, the proponents of dismemberment believe that the notion of Nigeria as a mere geographic expression (Awolowo, 1990) remains an undisputable fact as the forceful packaging of unwilling communities of diverse origin and culture under the same polity was done by colonial authoritarian fiat. Scholars have agreed that the forceful packaging of unwilling communities was one of the worst atrocities ever visited upon a people anywhere in the world.

Writing on the unspeakable state of affairs in the country, Ogundiya (2010) says Nigeria has remained a laggard in social, economic and political developments despite all social and economic policies that have been implemented by successive administrations. As it were, Nigeria has become a classic illustration of an oxymoron, a poor country in the midst of abundant human and natural resources. The oxymoronic state of affairs is clearly reflected in the abject poverty, acute youth unemployment, lack of transparency and accountability, inefficiency and ineffectiveness, lack of equity, fall in the living standard of citizens, social injustice and most worrisome, organized corruption and heightened crime rate, poor health prospects and widespread malnourishment since independence.

This is the tragedy of the Nigerian nation, which explains its crawling posture almost fifty eight years of political independence. Essentially, the crisis of leadership in Nigeria today is a sad commentary to the labours and sacrifices of her founding fathers, who were harassed, beaten and imprisoned for daring to stand up to the excesses of the colonial overlords. Were the dead allowed to rise again, these patriarchs would be shocked to behold what the modern politicians and their children have turned Nigeria into. This is despite the fact that Nigeria has enormous resources and huge potentialities to be a great country. Concurring with this assertion, Achebe (1983) rightly pointed out that "the trouble with Nigeria is simply and squarely a failure of leadership. According to him, "there is nothing basically wrong with the Nigerian character, there is nothing wrong with the Nigerian land or climate or water or air or anything else," the problem is based on leadership (Achebe, 1983). As a result, the agitation for splitting of Nigeria into its former constituent units is on the rise daily.

\section{Statement of the problem}

The emergence of terrorism orchestrated by Boko Haram and Fulani herdsmen deadly attacks has caused the decimation of thousands of innocent Nigerians lives, majority of who are Igbos and Christians who have been killed in the attempt to impose Islam as a state religion. Thus, the dangerous trend that insecurity has assumed in the country with bombing of everything within reach including innocent people, even women and children is frightening. Calls for splitting of the country are gaining momentum. Basically, from the activities of Boko Haram, Nigeria has now been certified as a fully fledged terrorist state, a classification that brings untold odium on us all. Several violent attacks by the Boko Haram have affected economic activities in the north-east states of Maiduguri, Yobe, Bauchi, Gombe, and Adamawa and also other cities such as Taraba, Kaduna, Plateau, Benue, Nassarawa and Kogi States as many residents, particularly Christians and Igbo Indigenes have fled their homes while others who could not relocate 
hardly go about their normal business. The bombs, despite the presence of the country military are still flying, killing several hundreds of innocent people Christians and Igbo Indigenes.

\section{Methodology}

The study adopts the snow-ball sampling technique since it was hard to find or recruit participants for the study. Almost all returnees from northeast Nigeria have become poorer than they were; it was difficult locating them as many had become implicit, and withdrawn. However, since it was imperative to get the responses from these forced returnees in order to get their' experiences and the expressions of such experiences in a way as close as possible. To this effect, the snow ball sampling technique was adopted. In employing this sampling technique, the researcher was able to get one participant through interactions and thereafter, picked up more "snows" along the way and in the process; the snows became larger and larger and grew up to 50 participants. Snow as used here implied participants. Data generated were subjected to systematic analyses with a view to making inferences on the interface among the substantive variables of study.

\section{Theoretical framework}

We strive to gratify our wants and desires, our goals, aims, and ambitions. But when we are often unable to satisfy our desires or accomplish our goals, we vent our frustration on others who may not be connected to our inability to achieve our goals. We aggressively accuse them as being responsible for our inability to improve our deplorable conditions or situations. This is where the basis of Frustration and Aggression theory becomes important in this work as it pertains to the forced migration of Igbo Indigenes from northeast to southeast Nigeria.
The origin of Frustration and Aggression theory can be linked to the publication of Dollard et al. (1939) which they presented 'what is now popularly called the frustration-aggression hypothesis (F-A). These proponents assert that the central thesis of Frustration and aggression theory is that aggression is always a function of frustration and the occurrences of aggressive behaviour always presuppose the existence of frustration. One of the major tenets of the theory is its ability to cause any hostile or aggressive behaviour that occurs as a result of frustration.

The theoretical significance of this theory to the this study is its ability to concisely explain the reasons for Boko Haram terrorist activities against Igbo Indigenes whom they have massacred and their properties destroyed as if they were the cause of the decades of failed government and elite delinquency in Northern Nigeria, particularly northeast finally ripening into social chaos. The irony of the situation is that those who were most deprived, most oppressed, most in need, like the Igbos, did not resort to terrorism. The irritation, anger and frustrations of the failure to foist Islam as a state religion on a pluralistic state like Nigerians have been visited upon the Igbo Indigenes. In nutshell, the Igbo indigenes have become scapegoat for the failings of the northeast elite. However, a clear picture of the aggression and frustration emerges when one notes the subscription to Western education by Igbo indigenes as against the wish of Boko Haram. The incessant killings of Igbos, Southern Nigerian/Middle Belt innocent Nigerians, including the destruction of their properties running into billions of naira were a way of venting their aggression and frustration. It is in this vein that Obioma (2009) asserts that the Boko Haram terrorist activities is undoubtedly the most blood thirsty and destructive both in terms of its demonic brutality, 
mindless savagery and increasingly in scope of operation.

\section{Review of literature and conceptual clarification}

\section{National Security and the Boko Haram challenge}

National security has been defined as the ability of a nation-state to, among other things, preserve the nation's physical integrity and territory; to maintain its economic relations with the rest of the world on reasonable terms; preserve its nature, institutions, and governance from outside; and to control its borders (Unumen, 2014) and Oghi and Unumen, 2014). The ability of states and societies to maintain their independent identities and functional integrity is also an integral aspect of national security. The main objective of national security is to uphold a country's national values, which include national survival, self preservation, territorial integrity and economic progress (Abidde, 2014). What constitute terrorism and terrorist acts have engaged the attention of scholars and analysts over the years. However, there is no generally acceptable definition of the terms (Oghi and Unumen, 2014).

The activities of Boko Haram have, according to Chukwu (2013), become the very first set of serious thoughts that come to mind wherever the issue of security is raised, particularly as it concerns the survival of the country's nascent democracy. Despite the fact that democracy provides and allows conflicts in society to be resolved by rational argument and persuasion rather than by violent coercion, the activities of Boko Haram, the ultraviolent Islamic militant group that hinges the killings and other abuses against Igbos on decades of failed government and elite delinquency in the Northern States have defiled all rational reasoning. Essentially, the unwholesome activities of Boko Haram have been impacting negatively (Abimbola and Adesoji 2012) on the various segments of society; creating the psychological basis for arbitrariness. The detestable killings and abuses by Boko Haram are only the maturation of long festering extremist impulses that run deep in the social reality of Northern Nigeria, but the incessant bombs explosions that send hundreds to early graves.

Going by the latest report from the Human Rights Watch (HRW), about 935 has been killed since 2009 when the sect began its onslaught on the country. From this exposition, the Boko Haram uprising, Adesoji (2010) argues, attracted attention not only because the legitimacy of a state was challenged in the course of promoting Islamic revivalism, but because its outbreak was an indictment of the state whose seeming ineptitude was becoming apparent with regular outbreaks of violence of many kinds despite the state's continuous promises to check them. Thus, the commitment of bombing of churches and wanton destruction of properties, including loss of lives has propelled the forced migration of Igbos to their states of origin.

Consequent upon this development, Igbo have been forced to withdraw their presence from all affected areas of the northeast states due to the bombing of churches, markets, and other series of senseless killings of huge number of them at crowded squares. Unfortunately, these religious murderers and arsonists have never been arrested; would never be arrested as long as they continue to enjoy unmitigated impunity. This hypocritical stance by government is compounded by the intense use of State authority to cover up these barbaric and unwholesome activities, which have in the final analysis impacted negatively on the various segments of Nigerian society. For example, the unconstitutional act of chasing and hacking to death suspected blasphemers of Islam remains dreadful. The case of Akaluka, an Igbo Christian, taken out of police custody, killed and beheaded, and 
having a triumphant procession with his head held aloft right in the presence of law enforcement agencies remains evergreen. With this, who says Igbo still do not have a right for self determination which they seem to be demanding through a non-violence means?

Prior to the quit order declaration, Nigeria's foremost novelist Chinua Achebe has claimed that Nigerians, especially of the Hausa/Fulani and the Yoruba stocks, do not like his Igbo ethnic group because of the southeast's cultural advantage. He made this claim in his new book: There was a Country, which has generated controversy for his onslaught on the role of Obafemi Awolowo as the Federal Commissioner of Finance during the Nigeria Civil War. He accused Awolowo of genocide and imposition of food blockade on Biafra, a claim that has drawn rebuttals and contradictions of emotional intensity from some southwest leaders and commentators. According to Achebe:

I have written in my small book entitled The Trouble with Nigeria that Nigerians will probably achieve consensus on no other matter than their common resentment of the Igbo.

Achebe traced the origin of "the national resentment of the Igbo" to its culture that "gave the Igbo man an unquestioned advantage over his compatriots in securing credentials for advancement in Nigerian colonial society. He observed that the Igbo culture's emphasis on change, individualism and competitiveness gave them an edge over the Hausa/Fulani man who was hindered by a "wary religion" and the Yoruba man who was hampered by" traditional hierarchies." He therefore described the Igbo, who are predominantly Catholic, as "fearing no god or man, was "custom-made to grasp the opportunities, such as they were, of the white man's dispensations. And the Igbo did so with both hands.

Fundamentally, the emergence of Boko Haram signifies the maturation of long festering extremist impulses that run deep in the social reality of Northern Nigeria (Adesoji, 2010). But the group itself is an effect and not a cause; it is a symptom of decades of failed government and elite delinquency finally ripening into social chaos. Northern Nigeria is a seething mass of illiteracy, misery, poverty and beggary. While Nigeria generally scores very poorly on every index of human development, Northern Nigeria sinks below the abysmal national average to the extent that a child born in the northwest or in the northeast is likely to have a lower quality of life than a compatriot born in the southwest or southeast. In this regard, Boko Haram is the consequence incarnate of misrule by delinquent political elites of the northeast who have or less converted collective funds into private and family estates. Substantiating, some scholars have asserted that there is a legitimacy crisis, occasioned by problematic national cohesion, contested citizenship, and violent contestation for state power, perennial challenges to the validity and viability of the state, and massive loss and exit of citizens through internal displacement, refugee flows, separatist agitation, civil war and the like. In addition, they maintain that there is an unstable and divided population, suffering from a torn social fabric, minimum social control, and pervasive strife that encourage exit from rather than loyalty to the state.

It is based on these
characteristics and theoretical
underpinnings that it becomes
appropriate to classify Nigeria as a
fragile state because a majority of the
characteristics sketched out above are
clear features in the country. Thus, one
finds a link between Nigeria's weakness
and the emergence and dynamics of
terrorist operations in the country,


especially from the Boko Haram group which has propelled the forced migration of Igbo from the troubled northern Nigeria. As a result, the need for agitations for self determination becomes a better option in the prevailing circumstances which in the foreseeable future will remain same.

Terrorism and the upsurge of the agitations for the actualization of Biafra

Nigeria has over the past years, properly speaking, prior to independence, been experiencing tremendous changes both politically and economically with series of threats of dismemberment on different occasions. First among all the threats into its previous component units has been the mutual suspicion and invidious hatred that characterized the union called Nigeria. All the unwilling communities of diverse origin and culture unwillingly packaged by colonial authoritarian fiat into one polity are yearning for a breakaway because the intercourse was wicked from all perspectives. As strange bed-fellows, who were only coerced into the Nation-State via amalgamation, the British did not construct Nigeria for internal coherence, but rather for their administrative convenience (Shively, 1997). Many of the countries past national leaders did not obfuscate their tribal over national loyalties. Some openly claimed that they were better off left alone in their tribal grouping than be constrained in a geographical salad bar called Nigeria.

While all attempts were being made to remain as one indivisible entity despite the differences which many seem to agree are slight, the outburst of terrorism via Boko Haram, the ultraviolent Islamic militant group that condemns western education, has embarked on a widespread and incessant killings of Igbos in some selected Northern States, particularly the northeast. Bombs explode regularly, killing huge numbers of people, especially at crowded squares in these states. Igbos who, dominate the Northern commercial landscape, have in their large numbers have been one of the worst hit. The unwholesome activities of Boko Haram have impacted negatively on the various segments of society; creating the psychological basis for arbitrariness. As it were, it was in view of this anomaly that the late sage, Obafemi Awolowo, once Nigeria described as a mere geographic expression (Awolowo, 1990). In the same vein, the Sarduana of Sokoto, Ahmadu Bello, echoed that the amalgamation by Britain of the North and South of that part of West Africa into one country called Nigeria is a grave mistake of 1914. Similarly, Awolowo (1947) had earlier, said:

All these incompatibilities among the various peoples in the country militate against unification. For one thing they are bound to slow down progress in certain sections, and on the other hand they tend to engender unfriendly feelings among the diverse elements thus forced together $[\ldots]$

Substantiating this position earlier, Time Magazine (1968) stated:

They were brought forcibly together under colonial rule; the three regions developed the hatreds and jealousies of totally different cultures. Most hated of all - and most envied by other Nigerians - were the Ibos(sic), quite possibly Africa's most capable people and, by force of energy and intellect, the dominant tribe(sic) of newly independent Nigeria (Time Magazine, August 23, 1968: 21)

Ever then, fear, suspicion and mistrust among different ethnic groups including hatred seem to be an overt historical and social phenomenon that had made the Nigerian state become an unstable, hegemonic and an illegitimate contraption. The present existing instability, chaos and unhealthy 
politicking in the country are not unconnected with the series of senseless killings of huge numbers of Igbo Indigenes at the least provocation. Also, there have one threat too many that snowballs into large scale conflicts leading to loss of hundreds of lives and properties worth billions of naira destroyed. Sequel to this, scholars have argued that relations and political behaviour in what is now called Nigeria has been characterized by mutual suspicion and invidious hatred.

Aside the sad tales of the defeat of Igbos in the ill-fated civil war, Igbo have been marginalized in all facets of governance. Marginalization, according to Oha-Na-Eze (1999), is the deliberate disempowerment of a group of people in the federation politically, economically, socially and militarily, by another group or groups, who during the relevant time frame wield power and control the allocation of materials and financial resources at the centre of the federation. Extending this definition, marginalization necessarily presupposes the existence of an agent, group or groups, which possess the capacity to disempower others or systematically exclude them from the seat of power, where the group's decisions are made. There is no evidence of a deficit of attributes in any area of modern development. But for other entirely different and sinister reasons, the abortive attempt at ethnic cleansing directed at the group through a civil war has presently been transformed into an on-going policy of systematic disempowerment in all sectors. For example, through boundary adjustment, some mineral - rich areas of Igbo land were transferred to Rivers and Akwa Ibom States. As the TSM (October 4, 1993) reported, the Obasanjo regime in its boundary adjustment exercise in 1976 pushed the Ndoni/Egbema area and parts of Ndoki South of the Imo River, which harbour the highest petroleum deposits in Nigeria, into Rivers State. Besides this, the Federal
Government ignored, as a non-issue, mineral finds within Igbo land (probably because the sites could not be merged with non-Igbo areas). Oil find in Nsukka area by SAFRAP (a Federal Oil Company) was sealed up with the expulsion of the Company during the war, and till date the Federal Government has not ordered resumption of activities in the sealed up site. Natural Gas find in Ugwuoba, the largest deposit in Nigeria, has also been sealed up as strategic reserve. It is also fundamental to note that the creation of States structure by General Yakubu Gowon on May 27, 1967, was an act of expediency aimed primarily at completing their siege of Igbo and frustrating their survival and struggle for self-determination. It dismembered the people into fragments and put into different Igbo States. Thus, there were Igbo of Port Harcourt, Ahoada, Ikwerre/Etche divisions placed into Rivers State, Igbo of Asaba, Aboh and Ika pushed into Mid-western States (part of today's Delta State), some others placed in the present day Akwa Ibom and Cross River States. The rest were isolated and land-locked into the East-Central State (today's five Igbo states of Abia, Anambra, Ebonyi, Enugu and Imo). This act was calculated to paralyze Igbo and incites their neighbours against them. With this revelation, whether admitted or not, Ekwe-Ekwe (2011) is of the position that Igbo are arguably the world's most brutally targeted and most viciously murdered of peoples presently. Earlier, Odumegwu-Ojukwu (2000) had argued that the reason for Igbophobia is unfathomable:

...Over the years, nobody can explain, why is it that when Igbo quarrel with Yoruba, Igbo are killed, when Igbo quarrel with Hausa, Igbo are killed, when Yoruba quarrel with Hausa, Igbo are killed. . ., Eventually, people say enough is enough, we can't this .. . What happened on Sharia issue is also the frustration which the (Igbo) youths have. They just can't understand the apparent Igbophobia 
in Nigeria (Odumegwu-Ojukwu, 2000:14).

Based on this verifiable evidence, Igbo people on the thrust of the terrorist activities of Boko Haram and Fulani herdsmen, have advocated autonomy for their people, although amongst Nigerians there appear to be differences of opinion as to whether Igbo are seeking autonomy within the Nigerian federation, or aspiring to the creation of a separate republic. Whichever, it is essential to acknowledge the fact that the concept of right to self-determination ascended after the formation of nation states. Corroborating this statement, the protagonists of the French Revolution spread the idea that the nation has a right and an identity of its own. Sovereignty was lodged squarely in the nation. In essence, the rise of nationalism coincided with the growth of some democratic ideas and sentiments: Liberty, Equality, Fraternity, National honour, National self-determination, popular and national sovereignty was inescapable components of the doctrine of nationalism.

Accepting the forgoing as an irrefutable fact, the right to selfdetermination is a right which reflects the importance given to communities, collectives and families in many societies and the general inherent communal quality of humans. The purpose of the protection of this right is to enable these communities as communities to prosper and transmit their culture as well as participate fully in the political, economic and social processes, thus allowing the distinct character of a community "to have this character reflected in the institutions of government under which it lives". It also forms part of the empowering process of human rights. Thus the right protects people from being subject to oppression by subjugation, domination or exploitation because, as the African Charter makes clear, "nothing shall justify the domination of a people by another"
(McCorquodale, 1994). It is also seen as a right of dominated peoples to achieve equality in relation to those who dominate them. The International Court of Justice (ICJ) refers to the right to self determination as a right held by people rather than a right held by governments alone (Parker, 2000).

From the foregoing, it is crystal clear that the Igbo enjoy less protection of the law than any other ethnic group in Nigeria. In lamentations, Kalu queries why simply being Igbo and entrepreneurial, the Igbo man in any setting is adjudged guilty, dehumanized and attempts fiercely made to annihilate him. Regretfully, this is not unconnected with a perverse group that has always lays claim to leadership in this country. Without appreciating the importance of the right to self determination, some youth organizations in the northern part of the country which included Arewa Citizens Action for Change, Arewa Youth Consultative Forum, Arewa Youth Development Foundation, Arewa Students Forum and Northern Emancipation Network converged at the Arewa House in Kaduna on June 6, 2017 with several other people in their region. The youths reviewed the current position of the North, particularly on the non-violence posture of Igbo on their rights to self determination and jointly came up with the quit order declaration for Igbo. By implication, Igbo were to vacate from northern states on or before Oct. 1st, 2017. According to the group, the shutting down of major towns in the South East on May 30, 2017, as part of the campaign by the Indigenous People of Biafra (IPOB) for the actualization of Biafra Republic and similar confrontational conducts amount to a brutal encroachment on the rights of those termed as non-indigenous people residing and doing lawful businesses in those areas illegally demarcated and defined as Biafra, are downright unacceptable and shall no longer be tolerated. The question that begs for answer remains: How did the 
infringement of the rights of others allegedly levied against Igbo carried out peacefully and in agreement with the objectives of non-violence angered the Arewa group?

Prior to the quit order, Oha-NaEze (1999) had earlier asserted that the process of marginalization of Igbo was ab initio built into a gross injustice perpetrated through the creation of states and local governments as juicy as the basic units of sharing of federal amenities. From being one of the three main ethnic groups in Nigeria, Igbos have today progressively reduced through geopolitical manoeuvres and demographic manipulations to a minority status. Their cries of marginalization have become a singsong. In her petition to the chairman of the 'TRUTH AND RECONCILIATION PANEL' (Established to ascertain the truth and effect reconciliation between persons and also among the federating units that make up Nigeria by the President Olusegun Obasanjo), the late sage, Justice Chukwudifu Oputa (Oha-NaEze, 1999), contended that the official mind-set of preemptive malice and genocidal siege strategy which prompted the maiden national exercise of warwinning 12-states structure of 1967 has apparently continued to guide subsequent exercises. Accordingly, the Eastern part otherwise called Igboland has only five States while North West seven, and others six each. Each state of the federation is divided into three senatorial districts; the South East with five states has 15 senatorial districts. This is a sharp contrast to the 18 senatorial districts possessed by each of such zones as South-South, South West, North East and North Central, even though there is one senatorial district for the FCT Abuja. Both politically and economically, the socio-cultural Igbo group, Ohaneze, asserted that the situation in Nigeria is that number of states per geo-political zone is the major determinant factor for distribution of Federal appointment/employment, development projects and of course the usual sharing of Federation account. This scenario therefore makes every segment of the political horizon target for development.

The histories of nations, according to Kalu (2013), are replete with evidence of existential threat to any group whose marginalization is made a subject matter of constitutional enshrinement. In his assessment of the historical plight and precarious future of Igbo people, he argued that with unequal voice in the Federal Executive Council, in the National Assembly, on the federal judicial benches and a vast array of others for which they suffer sub-parity representation, the strength of the advocacy of their problems and priorities is thus diminished. Little wonder then, he averred that the South-East Zone, the area inhabited by the Igbo, still manifests the physical characteristics of a conquered and occupied land, 48 years after the civil war. Quite apart from the psychological assault it represents for Igbo people, the practical issues of unequal representation and unequal allocation of resources are calculated to retard the development of the region and the people too. The massive difference which the resources and human empowerment that they are denied might have made in their society something that calls not just for a sober reflection but a gritty resolve to bring about their speedy resolution. However, he concluded that the Igbo tenacity, drive and relentless optimism to pursue life's enduring dreams of family, faith and success and to overcome life's challenges would see them through. But the world must listen to them whenever they cry out. For they have long suffered and endured in silence, as the rain continues to beat them.

It is interesting to note that the concern for right to self-determination for Igbo or any other indigenous people are embedded in the issue of human rights. Human rights are rights held by individuals simply because they are part 
of the human species. They are rights shared equally by everyone regardless of sex, race, nationality, and economic background. They are universal in content. Across the centuries, conflicting political traditions have elaborated different components of human rights or differed over which elements had priority. The manifold meanings of human rights reflect the process of historical continuity and change that helped their present substance and helped form the Universal declaration of Human Rights adopted by the General Assembly of the United Nations in 1948 (Ishay, 2004).

Self-determination has been expressively acknowledged as a human right when it was included into the two international human rights covenants, the International Covenant on Civil and Political Rights (ICCPR) and the International Covenant on Economic, Social and Cultural Rights (ICESCR), which came into force in 1976 and constitute legally binding human rights treaties based on the Universal Declaration on Human Rights. The right of self determination is stated in common Article 1 of the ICCPR and the ICESCR. Common Article 1(3) of the ICCPR and the ICESCR then specifies the right in stating that the realization and respecting of it shall be in conformity with the provisions of the Charter of the United Nations. Yet, the content of the right of self-determination is not determined and leaves space for interpretation. As human rights have to be balanced with the particular and changing requirements of society, following general legal rules have been elaborated: first, human rights must be interpreted in the context of current standards; second, any limitations on the exercise of human rights are to protect either other rights or to protect the general interest of society; third, any limitations must be considered narrowly and in the context of specific circumstances; and finally, the victim of a human rights violation $\mathrm{n}$ must bring the claim.

Fundamentally, the right to self determination is indisputably a norm of jus cogens. Jus cogens norms are the highest rules of international law and they must be strictly obeyed at all times. Both the international Court of Justice and the Inter-America Commission on Human Rights of Organization of American States have ruled on cases in a way that supports the view that the principal of self determination also has the legal status of 'erga omnes'. The term "erga omnes" means "flowing to all". According, ergas omnes obligations of a State are owed to the international community as a whole: when a principle achieves the status of erga omnes the rest of the international community is under a mandatory duty to respect it in all circumstances in their relations with each other. Similarly, it has been argued that the right to self-determination is considered jus cogens, and a part of customary international law that imposes binding obligations on all nation states. It is considered not simply a principle of international law, but rather an affirmative right of all peoples. It is seen as a prerequisite to any genuine enjoyment of any of the human rights. But despite notable recognition of the right to self-determination, there is still a great deal of disagreement among states, and among international scholars, as to the scope and parameters of the right to self-determination, as well as who, exactly, is entitled to such a right.

Writing on the problem Nigeria faced and still faces contemporarily, the great literary icon, Achebe (1983) succinctly stated that:

The trouble with Nigeria is simply and squarely a failure of leadership. There is nothing basically wrong with the Nigerian character, land or climate or water or air or anything else. The Nigerian problem is the unwillingness or inability of its leaders to rise to the responsibility, 
to the challenge of personal example which are the hallmarks of true leadership... We have lost the twentieth century; are we bent on seeing that our children also lose the twenty-first? God forbid!

President Muhammadu Buhari has fortuitously reopened the debate about the fate of Nigeria as a corporate entity. At a meeting with the Emir of Katsina, Abdulmummuni Usman, the President declared that "the corporate existence of Nigeria is non-negotiable." He vowed to defend the unity of the country with his life, arguing that, having fought the Civil War, there will be no hesitation in crushing any agitation for a break-up. The President's position is understandable, but seriously contributing to the discourse, which unity is the President going to defend with his life when indeed the continued existence of Nigeria as presently constituted is said to be a fraud from an academic point of view? Perhaps, it is necessary to re-assert the views of Shively (1997) that Nigeria was a British colony; like most colonies, it was not constructed for internal coherence, but rather for the administrative convenience. Over 250 different languages and dialects are spoken within its borders, and there is also an important religious split, as the north is primarily Muslims and the south is predominantly Christians, two opposing religious groups. For all intents and purposes, commonsense holds that the notion of Nigeria was engendered by the forceful packaging by colonial authoritarian fiat of unwilling communities of diverse origin and culture under the same polity (Awolowo, 1990). Besides, the country is an artificial creation standing on a false tripod. For a long time, the country had pretended about its unity, since amalgamation, Nigeria has been a country where ethnic champions, religious bigots and political overlords hold sway. Thus, relations and political behaviour of the peoples have been characterized by mutual suspicion and invidious hatred since they are strange bed-fellows, who were only coerced into the Nation-State via amalgamation (Olu-Adeyemi, 2006).

From this exposition, one may be tempted to ask what is basically wrong in a people who feel marginalized, subjugated and discriminated upon for whatever reason(s) wanting to redefine their membership of the group that oppresses them. Be it as it may, one factor often advanced for the plight of Igbo in Nigeria was the attempt by the Aguiyi Ironsi regime to abolish regionalization in favour of a unitary system of government which was regarded as a plot to establish Igbo domination in the Federation. On 24 May 1966, Ironsi issued a unitary decree, which led to an explosion of attacks against the Igbo in Northern Nigeria on May 29, 1966. In regard to this, the British press was unanimous in its conviction at the time that these May 29 killings were organized and not spontaneous. In essence, the May 1966 pogrom was carried out by rampaging mobs with the connivance of local government (Horowitz, 1993). Consequent upon this, using Boko Haram, Muslim fundamentalists, Arewa Youth Congress and now Fulani herdsmen as tools, Christians and Igbo Indigenes have not only been dislocated from their means of sustenance, but also slaughtered in the way and manner rams and fowls are slaughtered. Is there therefore any rationality stopping their quest for the right of self autonomy and self rule? This autonomy of the person, which Christians and Igbo Indigenes seek, as in the Kantian philosophy, is often regarded as the source for the human dignity and gives the person its inherent value.

The natural rights of all humans are then deduced from this absolute value of the person. Sure, this conception of natural rights has been challenged and today even liberal theories of human rights are not necessarily based on the 
assumption of human dignity. But the general perception of the person as autonomous and capable of rational choices remains the bases of the liberal idea of the right of self-determination.

\section{Discussion of findings}

From the responses on terrorism and the forced migration of Igbo Indigenes from the northeast, all the 50 participants agreed that Nigerians were fully integrated despite their slight differences until the outburst of the terrorist sect, Boko Haram. Since its emergence, the group has not only unleashed violence on Nigerians and also heightened fears among them; it has also assumed a frightening dimension to the extent that human lives are no more sacred; people are being disposed as if they were rams and fowls. To this extent, they argued that the Boko Haram terrorist sect, besides making life miserable for Nigerians, has also inflicted much disunity to the corporate existence of Nigeria. And since the state which exists fundamentally for the protection of lives and property and ensuring the wellbeing of the citizens has failed, 30 participants representing $60 \%$ were unanimous that the enormity of destruction and carnage caused by Boko Haram terrorist sect surpassed any other attack carried out by any sect in the history of Nigeria as country. Similarly, 40 participants representing $80 \%$ of the total population were of the position that since amalgamation (1914), Nigeria had remained a mere geographical expression and therefore could break up if safety of lives were no longer guaranteed as envisaged. However, the other $20 \%$ of the participants despite being forced to return back to southeast countered that Nigerians could still be one united and indivisible entity despite the security challenges currently ravaging the country because there was much to be gained from being together than splitting into different Republics. They further argued that despite the fact that several hundreds of lives had been lost and properties worth billions of naira belonging to Igbos also destroyed, Nigeria could still be one if a good and responsive government was put in place. On the whole, 40 participants representing $80 \%$ asserted that Boko Haram terrorist activities contradicted National integration and had made Nigeria unstable, hegemonic and that the instability and chaos arising from the unhealthy rivalry amongst the different groups showed that the Nigerian situation was such that boycotted the due course of legitimization at formation and the discordant voices were merely manifesting that consensus and fair play would remain a mirage. 35 participants representing $70 \%$ of the total population held that unless there is remarkable improvement in the maintenance of security in the land, the Igbos and other southerners would never return to the northeast region. This was because Nigerians have been so incensed with the rising insecurity in the polity that they are calling for the country's disintegration.

The question bothering on the continued injustices suffered by Igbo Indigenes and the recent upsurge of the agitations for the actualization of Biafra, 38 participants, representing $76 \%$, rejected the view that agitations and acts that tended to depict the existence of another sovereign state when such "sovereign" state was not legitimate could not be tolerated by any serious sovereign state. They contended that the historical evidence was that the geographical structures of boundaries of nations were not cast in stone. The socialist Federal Republic of Yugoslavia, a construct of the Cold War, broke up in the Balkan conflicts in the early and mid1990s into separate and sovereign countries. Similarly, participants see nothing wrong if Nigeria breaks up just the same way and manner Czechoslovakia broke up and became two nations, Czech Republic and Slovakia. Closer home, a plebiscite 
administered in 1961 at the behest of the United Nations to determine the wishes of inhabitants of certain parts of Cameroon resulted in Northern Cameroon becoming a part of Northern Nigeria while Southern Cameroon joined the Republic of Cameroon. Aside this viewpoint, participants argued that international law provides some legal basis for the concept of selfdetermination of peoples. Thus, the agitators for Biafra were of the opinion that the southeast has been comprehensively and strategically marginalized today more than ever before in the history of Nigeria. Besides, it has been argued that the current wave of agitation for Biafra is a bye product of an accumulated deprivation, destruction, marginalisation, anger and frustration of the past visited upon the Igbos.

This shift in sentiment and perception has important implications for the continued existence of Nigeria as one united and indivisible entity. For one, if a referendum were held today on the subject of remaining or leaving the Nigerian federation, a majority would, in all likelihood, voted in favour of leaving Nigeria. The dramatic swing in pro-Biafra sentiment from marginal to mainstream in the southeast underscores the mismanagement of the nation-building challenge. The more important implication from a longer-term perspective was that struggles for freedom from oppression or domination tended to have an inevitable historical logic that almost always ended in success. It did not matter to the forced returnees (participants) how long it took, nor was this historical truth affected by the reluctance of dominant and powerful groups to recognize it. One particular participant, a Master's degree holder in International Relations, went memory lane. According to him, the biblical Jews were in slavery in Egypt for 430 years and were led to freedom by Moses and Joshua; the struggle for decolonization by numerous African and other colonized nations, the ultimate end of Apartheid in
South Africa, the end of slavery and the civil rights movement in the United States in the face of white racism and privilege that thought it would last forever, were just a few examples of struggles for self determination that eventually ended in freedom. Thus, the participant concluded his thesis by arguing further that as a Biafra campaigner, the long arc of history is on their side. By implication, ridiculing them by references to their relative youthfulness missed the point as their resolve is steely and their fervor driven precisely by their youth. The danger now, which must be prevented, is that some in these groups may be increasingly radicalized and tempted to take up arms against Nigeria tomorrow if government which has now zoned all sensitive security architecture to the northern Nigeria does not restructure to ensure equity and fairness. Commenting on the present precarious situation in Nigeria, Juniad Muhammed, a former law maker, said:

... So, my experience is that one, to Buhari what matters most is that people he put in certain positions must be his relatives, his in-laws, blood relations and also most importantly be members of his inner circle. So, the idea of nepotism, the idea of prebaendalism, the idea of giving a man an opportunity only because you know and he is your friend is something I find terribly objectionable. This is the worst government in the history of Nigeria that I know of since 1914 till date.

On the 2019 presidential election, he maintained that failure to ensure free and fair election in 2019, "there may not be Nigeria again"

\section{Conclusion}

Terrorism has been a global menace which affects economic, political and social status of the country experiencing it. These terrorist activities 
of the Boko Haram sect have culminated in the forced migration of Igbo Indigenes from northeast where they had been massacred and their properties running into billions of naira destroyed; this has clearly shown that the state of insecurity in the polity has assumed a frightening dimension and, Nigeria is at the verge of splitting into their distinct nation states foisted together by the British authoritarian fiat. Therefore, keeping Nigeria as one corporate entity has become the biggest headache going by the continued terrorist activities of Boko Haram sect. While it may be agreed that terrorism is a global problem, however, what looks rather strange is Nigeria's situation is the seeming inability of the government to tackle the challenge headlong. Boko Haram, Fulani herdsmen and gun attacks on innocent Nigerians, particularly on Christians and Igbo Indigenes have become almost a daily routine. While government is said to be hypocritically fighting terrorism, the quit order issued by the Arewa Consultative Forum to Igbo Indigenes is a terrorist act, but government instead of arresting their sponsors including one time Vice Chancellor has failed thereby fuelling the agitations for the actualization of Biafra. The famous poet, W.B. Yeast captures the scenario in this poem: Things Fall Apart thus:

Turning and turning in the widening gyre, the falcon cannot hear the falconer; Things fall apart; the centre cannot hold; Mere anarchy is loosed upon the world, the blood-dimmed tide is loosed, and everywhere the ceremony of innocence is drowned; the best lack all conviction, while the worst are full of passionate intensity

Given the danger terrorism poses and wishing the problem away, pretending it is not there, or that it is not as serious as it is, is akin to sitting on a time bomb. For hope to exist, therefore, all efforts should be directed at encouraging the role of the civil society in engendering good governance in
Nigeria. From all available literature, it is proven that the civil society reinforces mechanism for effective governance in the overall interest of the majority of the people as they possess the capability to cooperate with, engage, antagonize, contend and influence the state on behalf of the citizenry in a bid to social justice and equitable distributions of resources to Nigerians. That is to say, the civil society can be seen as an arena where the populace resists unpopular decisions and policies of government.

\section{Recommendations}

As it stands, the growing problem of insecurity arising from Boko Haram terrorism, Fulani herdsmen deadly attacks and the forced migration of Christians and Igbo indigenes from northern Nigeria leading to the upsurge of agitations for the dismemberment of the country appears to be more deeprooted than the approaches adopted by the Nigerian government to address it. However, wishing that all is alright, pretending that the country is at peace with itself, or that no disintegration will occur because of the president's threats, is akin to sitting on a time bomb.

Based on this, there is a great consensus among scholars, analysts and participants employed in this study that the country is currently in a state of siege, not only by threats of Boko Haram terrorist activities, or the Fulani herdsmen invasion but more seriously by the agitations for self rule by the various unwilling communities of diverse origin and culture forcefully packaged together by colonial authoritarian fiat under the same polity. Therefore, wishing that all is alright, pretending that the country is at peace with itself, or that no disintegration will occur because of the president's threats, is akin to sitting on a time bomb. As a result, the following are hereby proffered:

1. The government should assure the citizens, particularly Chris- 
tians and Igbo Indigenes who have fled northern states that the perpetrators would no longer operate with impunity. In this vein, there should be compensation on lives lost including properties destroyed to woo back these Igbo entrepreneurs to continue to develop the northeast economy and, by implication, the entire Northern economy as well as Nigeria.

2. No matter the temptation, and for whatever reasons, Government must desist from sponsoring terrorism in all forms including violent religious fanaticism through any means to distract the populace from bad governance. Since it is proven that the civil society reinforces mechanism for effective governance in the overall interest of the majority of the people, government should partner with them in a bid to bring social justice and equitable distributions of resources to Nigerians. That is to say, the civil society should be seen as an arena where the populace resists unpopular decisions and policies of government.

3. Since it has been observed that the persistent problem of terrorism has remained a threat to Nigeria's existence, government should halt the approaches hypocritically being adopted by the Nigerian government to address the menace of terrorism. The reason being that Nigeria's security challenges were incubated and hatched by bad governance resulting to poverty, hunger, injustice, corruption, unemployment, general government insensitivity and leadership failure thereby creating opportunities for terrorism to blossom. In this circumstance, only a shift in paradigm that guarantees the security of the human person to ensure freedom from 'want' and freedom from 'fear' can solve this puzzle. Human security is synonymous with development and good governance. It means food on people's table, quality education and safe drinking water for the people, employment, justice, environmental protection and economic progress. This paradigm shift is imperative if Nigeria must achieve remain as one indivisible entity.

4. Secondly, people can be killed, but ideologies cannot. The government should acknowledge the fact that while a person can be killed, an ideology can only be combated through good governance. Since good governance is usually understood to mean participatory democracy, the views of all oppressed groups, including women, youth and the poor should henceforth be heard and considered by government. In essence, good governance should be all inclusive. True participation relates to openness on the part of government in improving the welfare of the people. When there is improvement in the people's standard of living, the masses will support government and ideologies can be killed, but when there is false participation, the reverse is the case.

5. Government should create jobs fix the economy and halt the spread of corrupt practices. It has been established that suicide bombers are often motivated by welfare benefits for family members. The promise of monetary incentives to family members serves as a powerful motivator for new recruits. 
Having known that Nigerians are hungry and the biting economic situation has reduced Nigerians to either beggars or destitute, government should ensure that all the revolutionary changes taking place today, the many crucial courses of actions, policies and programmes embarked upon, are such that would improve the living standards of Nigerians today than ever before.

6. A breakdown in the constitutional and law enforcement machinery of the state also serves to promote anarchy and convince people to join terror groups. Therefore, all hands must be on deck to effect positive changes to curtail terrorism and terrorist attacks against Igbo immigrants.

\section{Conflicts of interest}

Authors declare that they have no conflict of interests.

\section{References}

Abidde, S. Nigeria's National Security in an age of anxiety. 2014. Available from: <http://thewillnigeria.com/opinion/7638>. Accessed on: Apr. 25, 2018.

Abimbola, J. O.; Adesote, S. A. Domestic terrorism and Boko Haram insurgency in Nigeria, issues and trends: A historical discourse. Journal of Arts and Contemporary Society, v. 4, p. 11-29, 2012.

Achebe, C. The Trouble with Nigeria.

Enugu: Fourth Dimension Publishers, 1983.

Achebe, $C$. There was a country: A personal history of Biafra. New York: Pearson, 2012.

Adesoji, A. The Boko Haram uprising and islamic revivalism in Nigeria. Africa Spectrum, v. 45, no. 2, p. 95-108, 2010. Available from: <https://journals.sub.unihamburg.de/giga/afsp/article/view/330/33 0>. Accessed on: Apr. 25, 2018.

Awolowo, 0. Awo on the Nigerian Civil War. Lagos: John West, 1990.
Awolowo, O. Path to Nigerian freedom. London: Faber and Faber, 1947.

Burgess, M. A brief history of terrorism. Washington, D. C.: Center for Defense Information, 2003.

Burke, E. Reflections on the Revolution in France. London: Penguin Books, 1790.

Chukwu, C.C. An assessment of religious threats to security and survival of democracy in Nigeria: A case study of the incessant killings of Igbos in some selected Northern states. Journal of Studies of Changing Societies: Comparative and Interdisciplinary Focus, v. 4, no. 10, p. 2358, 2013. https://doi.org/10.2478/scs-20140159

Chukwurah, D. C.; Eme, O.; Ogbeje, E. N. Implication of Boko Haram terrorism on Northern Nigeria. Mediterranean Journal of Social Sciences, v. 6, no. 3, p. 371-379, 2015. https://doi.org/10.5901/mjss.2015.v6n3p37 1

Dollard, J.; Doob, L.; Miller, N.; Mowrer, O.; Sears, R. Frustration and aggression. New Haven, CT: Yale University Press, 1939.

Ekwe-Ekwe, H. Readings from reading: Essays on African politics, genocide and literature. USA: African Renaissance, 2011.

Eme, O. I.; Ibietan, J. The cost of Boko Haram activities in Nigeria. Arabian Journal of Business and Management Review (OMAN Chapter), v. 2, no. 2, p. 10-32, 2012. Available from: <http://arabianjbmr.com/pdfs/ OM_VOL_2_(2)/2.pdf>. Accessed on: Apr. 25, 2018.

Ishay, $\mathrm{M}$. The history of human rights, from ancient times to the globalization era. 2 . ed. Berkeley, CA: The University of California Press, 2004.

Kalu, 0. The historical plight and precarious future of Igbo people. Vanguard, Apr. 21, 2013.

Kissinger, H. Foreign Relations, 1969-1976, Volume E-5, Documents on Africa, 19691972. Washington, D.C.: The White House, 1969. Available from: <https://20012009.state.gov/r/pa/ho/frus/nixon/e5/552 58.htm>. Accessed on: Apr. 25, 2018.

Krueger, A. B.; Malečková, J. Education, poverty and terrorism: Is there a causal connection? Journal of Economic Perspectives, v. 17, no. 4, p. 119-144, 2003. https://doi.org/10.1257/089533003772034 925 
McCorquodale, R. Human Rights and SelfDetermination. In: Sellers, M. (Ed.). The New World Order: Sovereignty, Human Rights, and the Self-Determination of Peoples. Oxford, 1994.

Mehmood, S. Terrorism and the macroeconomy: Evidence from Pakistan. Defence and Peace Economics, v. 25, n. 5, p. 509-534, 2014. https://doi.org/10.1080/ 10242694.2013.793529

Muhammed, J. Buhari's return in 2019 will end in tragedy. 2018. Available from: $<$ https://guardian.ng/interview/buharisreturn-in-2019-will-end-in-tragedy-saysjunaid-mohammed/>. Accessed on: Apr. 25, 2018.

Obioma, J. D. Boko Haram, domestic terrorism and the future of Nigeria. The Economy Magazine, 2009.

Odumegwu-Ojukwu, C. Sharia is a sabotage. Nigerian Newsatch, v. 31, no. 11, Mar. 30, 2000.

Oghi, E.; Unumen, J. O. Military intelligence and the challenge of national security in contemporary Nigeria. International Journal of Research in Humanities and Social Studies, v. 1, n. 2, p. 7-13, 2014. Available from: <http://www.ijrhss.org/ pdf/v1-i2/2.pdf>. Accessed on: Apr. 25, 2018.

Ogundiya, I.S. Democracy and good governance: Nigeria's dilemma. African Journal of Political Science and International Relations, v. 4, no. 6, p. 201208, 2010. Available from: <http://www.academicjournals.org/article/ article1381834964_Ogundiya.pdf $>$. Accessed on: Apr. 25, 2018.

Oha-Na-Eze, Ndigbo. The Violations of Human and Civil Rights of Ndi Igbo in the Federation of Nigeria (1966-1999): A call for Reparations and Appropriate Restitution. A
Petition to the Human Rights Violations Investigating Committee. 1999. Available from: <http://www.asabamemorial.org/ data/ohanaeze-petition.pdf $>$. Accessed on: Apr. 25, 2018.

Parker, K. Understanding self-determination: The basics. Proceeding on the First International Conference on the Right to SelfDetermination, United Nations Geneva, 2000. Available from: <http://www.guidetoaction.org/parker/self det.html>. Accessed on: Apr. 25, 2018.

Sederberg, P. C. Global terrorism: Problems of challenge and response. In: Kegley, W. (Ed.). The new global terrorism: Characteristics, causes and controls. Upper Saddle River, New Jersey: Prentice Hall, 2003.

Sherif, M. In common predicament: Social Psychology of intergroup conflict and cooperation. Boston: Houghton Mifflin, 1966.

Shively, W. P. Power and choice: An introduction to Political Science. New York: McGraw Hill, 1997.

Sidanius, J.; Pratto, F. Social dominance: An intergroup theory of social hierarchy and oppression. United Kingdom: Cambridge University Press, 1999.

Simon, J. D. The terrorist trap. Bloomington: Indiana University Press, 1994.

Unumen, J. O. Boko Haram movement in Nigeria and its implication for national security. In: Nwankwo, U. M.; Anaere, C. I.; Ayuba, J. M.; Akinwumi, O.; Olurode, L. (Eds.). Towards peace, security and sustainable development in Africa. Berlin, Germany: Mediateam IT Educational Publishers, 2014. p. 235-236.

License information: This is an open-access article distributed under the terms of the Creative Commons Attribution License, which permits unrestricted use, distribution, and reproduction in any medium, provided the original work is properly cited. 